\title{
The Social Justice Teaching Collaborative: A Collective Turn Towards Critical Teacher Education
}

\section{Brittany Aronson ${ }^{*}{ }^{1}$, Racheal Banda ${ }^{1}$, Ashley, Johnson ${ }^{1}$, Molly Kelly ${ }^{1}$, Raquel Radina ${ }^{1}$, Ganiva Reyes ${ }^{1,}$ Scott Sander ${ }^{1}$, Meredith Wronowski ${ }^{2}$}

* Corresponding author

E-mail: aronsoba@miamioh.edu

1. Miami University, Oxford, Ohio, USA

2. University of Dayton, Dayton, Ohio, USA

\section{Article Info}

Received: June 11, 2020

Revised: September 21, 2020

Accepted: September 25, 2020

\section{$10.46303 /$ icsr. 2020.8}

This is an Open Access article distributed under the terms of the CC BY 4.0 International license. (https://creativecommons.org/licenses/by/4.0/)

\section{How to cite}

Aronson, B., Banda, R., Johnson, A., Kelly, M. Radina, R., Reyes, G., Sander, S., \& Wronowski, M. (2020). The Social Justice Teaching Collaborative: A Critical Turn Towards Critical Teacher Education. Journal of Curriculum Studies Research, 2(2), 21-39.

https://doi.org/10.46303/icsr.2020.8

\section{ABSTRACT}

In this article, we share the collaborative curricular work of an interdisciplinary Social Justice Teaching Collaborative (SJTC) from a PWI university. Members of the SJTC worked strategically to center social justice across required courses pre-service teachers are required to take: Introduction to Education, Sociocultural Studies in Education, and Inclusive Education. We share our conceptualization of social justice and guiding theoretical frameworks that have shaped our pedagogy and curriculum. These frameworks include democratic education, critical pedagogy, critical race theory, critical whiteness studies, critical disability studies, and feminist and intersectionality theory. We then detail changes made across courses including examples of readings and assignments. Finally, we conclude by offering reflections, challenges, and lessons learned for collaborative work within teacher education and educational leadership.

\section{KEYWORDS}

Social justice teacher education, collaboration, critical theory 


\section{INTRODUCTION}

In 2000, Sonia Nieto argued that in order to put equity at the center of teacher education, schools and universities must "radically transform their policies and practices if they are to become places where teachers and prospective teachers learn to become effective with students of all backgrounds in U.S. schools" (p. 180). Since then, other critical scholars have argued the need for social justice to be a focus in teacher education (Cochran-Smith et al., 2009; Zeichner, 2009). Despite these calls to action, there are still few teacher preparation programs centering social justice across coursework (Liu \& Ball, 2019), and even fewer programs that require courses in race and ethnicity (Cook, 2015), gender and sexuality (Gorski et al., 2013), or disability studies (Annamma, 2015). In general, race, ethnicity, and whiteness continue to be undertheorized in teacher education (Harris et al., 2019).

These gaps in social justice teacher education (SJTE) are problematic given the "demographic divide" between a predominately white, heterosexual, female, monolingual, able-bodied teaching force who are charged with teaching an increasingly diverse student population (Enterline et al., 2008). Early career and pre-service teachers (PSTs) also report that they are underprepared to have conversations about race in their classrooms; only $31 \%$ of 386 surveyed teachers reported their teacher education programs prepared them for this type of social justice work (Milner, 2017). In agreement with these scholars, we argue that social justice is a crucial part of effective teaching and should be the core of teacher education.

In this piece we examine what it looks like when we, interdisciplinary faculty, collaborate to center social justice across multiple required courses in a teacher education program, located at a mid-sized predominantly white institution (PWI) in the Midwest. We also discuss how critical theories in education can be used to construct transformative curricula and pedagogy for PSTs. Representing Teacher Education, Educational Leadership, and Educational Psychology, we came together to form the Social Justice Teaching Collaborative (SJTC) within our college. In response to the tradition of minimal cross-departmental communication about curriculum and pedagogy at our institution, we formed this collective to un-silo our individual efforts in centering social justice in our courses required for PSTs. The formation of this group is a manifestation of our commitment to prepare culturally proficient and justice-oriented teachers. With the support of the College of Education, Health and Society, we worked on an interdisciplinary teaching grant which encouraged collaboration across departments. Our unique collaboration consisted of faculty from across departments with differences in power dynamics. At our initial inception, we were all either pre-tenured or contingent faculty (i.e. in a clinical role or a visiting assistant professor which is not a permanent position and holds heavier teaching loads). This meant that the charge to lead change within our college was initiated all by junior faculty in precarious roles. The position we held was actually pointed out to us by some of our senior colleagues who noted that doing social justice work is sometimes viewed as "risky," especially for junior faculty. However, with the grant support from our college, our Dean's and department chairs' support, and the support we provided each other, we pushed forward to do this work despite some of the resistance we faced from some faculty. 
Through the SJTC, we revised our curriculum and engaged in critical introspection of our teaching. Instead of adding a single course on social justice, our interdisciplinary work redefines the content and pedagogy across a sequence of required courses (i.e. Introduction to Education, Sociocultural Foundations, and Inclusive Education) to map a curricular trajectory for PSTs to learn about justice in education and practice the use of critical perspectives. In this manuscript, we highlight particular critical theories that inform our curriculum and pedagogy with PSTs. We then connect these theories into practice by re-imagining teacher education courses through a social justice lens. In providing a rich exploration of our practice in preparing "PSTs to engage with student diversity in socially just ways" (Mills \& Ballantyne, 2016, p. 263), we address a gap in literature about what justice-orientated teacher education looks like in practice, particularly from a collaborative standpoint.

\section{COLLECTIVE FOUNDATION GUIDING THE SJTC}

In our collective work, we align ourselves within the larger framework of critical social justice teacher education (CSJTE). Sensoy and DiAngelo (2017) point out that the concept of social justice moves beyond a notion of fairness and equality for all people, explaining a critical social justice (CSJ), "recognizes society is stratified (i.e., divided and unequal) in significant and farreaching ways along social group lines that include race, class, gender, sexuality, and ability. Critical social justice recognizes inequality as deeply embedded in the fabric of society (i.e. structural), and actively seeks to change this" (p. xx). From the beginning of our collaboration, we realized that as CSJ educators, we must have a collective vision of teaching and learning (Villegas \& Lucas, 2002). Since 2017, we met regularly to discuss central frameworks and goals that currently guide our work. One of the tasks accomplished was to develop our own definition of social justice to operationalize through our curricular revisions and teaching. For us, social justice teaching is:

A mindset, orientation, a way of thinking, and teacher identity that encourages dialogue among learners. It is a method that explores the emotional and moral dimensions of learning, facilitates problem solving, and interrupts normative narratives. It promotes social awareness and an ongoing process of critical consciousness toward self in relation to others.

The implementation and practice of this definition is guided by what we call the "north star," or linchpin, that rests on critical theories that question power dynamics in education. Below are the main critical theories that shape our teaching. These lenses also foster the development of critical thinking and agency for our PSTs to work towards socially just and transformative teaching practices.

\section{Critical Pedagogy}

While there is no unified definition of critical pedagogy, several tenets help explain its usefulness in classrooms. Proponents of critical pedagogy disrupt and challenge the status quo 
through a "variety of tools to expose... oppressive power politics" (Kincheloe, 2004, p. 50). A key component of critical pedagogy is emancipation through uncovering sociopolitical forces shaping schools. Critical pedagogues understand there are multiple forms of power along the lines of race, gender, class, sexual orientation, and other social identities. These forces are legitimized as natural and inevitable through day-to-day routines and social structures, such as schools. Additionally, critical pedagogues recognize the discursive power of language "defined as a set of tacit rules that regulate what can and cannot be said, who can speak with the blessings of authority and who must listen, whose social constructions are valid and whose are erroneous and unimportant" (Kincheloe, 2004, pp. 55-56). In school, this is normalized through required texts, accepted belief systems, definitions of success (i.e. standardized testing), and approved instructional methods (Kincheloe, 2004).

bell hooks, a critical pedagogue, weaves feminism with Frierian (1970) thought to create an engaged pedagogy. hooks (1994) encourages educators to be aware of how knowledge is produced and transmitted in the classroom. Teachers should teach to develop critical consciousness and work toward emancipatory education. A teacher's work is not just about sharing information, but also holistically healing and nurturing the intellect and spiritual growth of students. This contrasts with the "banking system" of education in which teachers deposit knowledge into students (Freire, 1970). Through critical thinking, hooks re-imagines the possibilities of teaching and learning. hooks' (1994) concept of engaged pedagogy also stresses that "excitement could co-exist with and even stimulate serious intellectual and/or academic engagement" (p. 7). Classrooms do not need to be ruled by rote learning in order to be considered rigorous. Teachers can help students tap into a passion for thinking, learning and creating new knowledge in ways that are both collaborative and engaging. These strategies are not a "blueprint" for teaching, rather they must constantly adapt to meet the needs of students. Finally, hooks explains that engaged pedagogy emphasizes well-being and a commitment towards reflection, and self-actualization of the teacher.

\section{Democratic Education}

Within our courses we touch upon theories related to progressivism, commonly referred to as democratic education, which emphasizes how schooling incorporates civic aspects of selfgovernance, community engagement, and experiential learning (Dewey, 1938). To understand how democracy and education are inextricably linked, we need a clear understanding of democracy beyond political mechanics such as voting, constitutions, courts, etc. (Quantz, 2016). Hytten (2017) explains, "Democracy is more than a political system or process, it is also a way of life that requires certain habits and dispositions of citizens, including the need to balance individual rights with commitments and responsibilities toward others" (np). Spring (1985) challenges some key political purposes of schooling like meritocracy and Americanization as contradictory and problematic. hooks (2010) contends that schools do not teach students what democracy actually is or how to engage in it, leaving "most students simply assume that living in a democratic society is their birthright" (p. 14) and not something that must be reworked and 
reimagined. Additionally, marginalized students may be excluded from this "birthright" altogether. Unlike critical pedagogy, democratic education does not always share an explicit social justice agenda (Dover, 2013). Collins (2009) argues that democracy is not a finished product and questions what counts as legitimate knowledge in the U.S.; specifically, "do the ideas of some people count more than others?" (p. 5). The answer "yes" is shown throughout history. John Dewey is often credited as the "father of progressivism" and promoting the idea that an American democracy requires an educated citizenry. However, Black and marginalized theorists like Anna Julia Cooper, W.E.B. DuBois, and Jane Addams also acknowledge that social justice is central to democracy.

\section{Critical Race Theory and Critical Whiteness Studies}

Critical Race Theory (CRT) is a theory and movement that stems from critical legal studies to examine the role of race, racism, and whiteness in society. CRT aims to "[transform] the relationship among race, racism, and power" (Delgado \& Stefancic, 2012, p. 3) to address social inequities. While there are no definitive core tenets to CRT, there are seven commonly cited tenets:

1) racism is permanent and an endemic part of U.S. Society (Bell, 1992);

2) people of color's interests are met when whites' interests are also served (i.e. 'interest convergence' (Bell, 1980));

3) counter-narratives (Bell, 1992) expose and challenge dominant "master narratives" in society ;

4) race is socially constructed;

5) whiteness functions 'as property' (Harris, 1993);

6) while racism is a primary tool of analysis, it intersects with other forms of oppression, e.g. sexism and classism--what Crenshaw (1991) terms 'intersectionality'; and,

7) social justice must be a commitment.

Additionally, Critical Whiteness Studies (CWS) stems from the broader work of "whiteness studies" by scholars like Peggy McIntosh or David Roediger, however, Black literary scholars such as James Baldwin or Toni Morrison were writing about whiteness long before it was "academized" (Leonardo, 2013). In regards to teaching, CWS shifts the question from "what does it mean to be a person of color?" to, "what does it mean to be white?" This is an important framework when helping white teachers understand their culture, themselves as racialized, and how privilege and power function in U.S. schools. Matias and Mackey (2016) explain, "[CWS] uses a transdisciplinary approach to investigate the phenomenon of whiteness, how it is manifested, exerted, defined, recycled, transmitted, and maintained, and how it ultimately impacts the state of race relations" (p. 34). Therefore, we use CRT and CWS in tandem to 
understand how racism is systemic and institutionalized in society and how whiteness impacts teaching.

\section{Critical Disability Studies in Education and DisCrit}

Critical special educators Annamma, Connor, and Ferri (2013) contribute the theoretical framework of DisCrit to analyze race and disability status. This framework also informs scholarship and praxis in social justice for disabled students of color. DisCrit extends the work of the theoretical frameworks of CRT and Disability Studies in education to illuminate how disability and race shapes injustices in schooling, such as the disproportionate representation of students of color receiving special education services and the school-to-prison pipeline that disproportionately impacts disabled youth of color. Annamma et al. (2013) point out that while "ability and racial categories are socially constructed, they continue to have real material outcomes in terms of lived experiences" (p. 9). Within CRT/DisCRT, it is understood that race and disability are social constructions fraught with bias that continue to perpetuate inequality in society and thus schools. Nevertheless, these categorizations have real implications for those whose bodies are racialized (i.e. Black or Brown) and/or disabled. The experiences faced by students of color and/or with disabilities are important to acknowledge given we live in a society that emphasizes their labels and, more importantly, their oppression. To be clear, when talking about disabled students, we are not suggesting that they are not students who have impairments (i.e. cerebral palsy) that might require different types of support to navigate schools. However what DisCrit scholars emphasize is it is not the student who is disabled, but rather society that is disabling the student (i.e. not having access to an elevator).

Building from the tenets of CRT, DisCrit examines the interlacing of racism and ableism and also values the examination of intersectional identities. Like CRT, DisCrit recognizes "gains" in the disability community have largely been a case of interest convergence of white, middleclass citizens. Additionally, DisCrit advocates for allyship, activism, and resistance. DisCrit considers legal and historical aspects of disability and race, legitimizing the lived experiences of People of Color and people with disabilities. Finally, DisCrit aims to amplify voices of marginalized populations. In these ways DisCrit creates a meaningful consciousness for teachers, teacher educators, and teacher candidates in their work towards disrupting the social injustices for students of color with disabilities (Annamma et al., 2013).

\section{Feminist Theories}

Feminist theorizing from the experiences of people/women of color also offers pedagogical and curricular possibilities for all educators to consider in their teaching. Feminist scholars draw from the situated experiences of individuals to generate theories that explain social reality and what it takes to create social change (Harding, 1987; Collins, 1990). It is through everyday experiences in personal interactions, within institutions, and across society at large that feminists understand how structural, interpersonal, and cultural dimensions of power are constructed and perpetuated (Collins \& Bilge, 2016). Intersectionality is an analytical lens that has a long history within the experiences, history, and theorizing of ordinary women of color, 
women of color activists, and feminist of color scholars (Crenshaw, 1991; Moraga \& Anzaldúa, 1983). This lens has played an integral role in education to unravel how students across contexts differentially experience privilege and oppression due to multiple intersecting hierarchies of power across race, class, citizenship, gender, sexuality, ability, and language (Elenes, 2001). Feminist educators have also integrated intersectionality as a pedagogical orientation to critically reflect upon their teaching and curricular decisions (Naples, 2009) to create a more inclusive learning environment.

Feminist perspectives have also led to the development of care theories in education. Noddings (2013) emphasizes the relational practices that women typically embody as they develop morality, ethics, and selfhood. Within this framework, morality is crafted through intimate interactions between the one who cares and the one who receives care. Everyday interactions and relationship building between the teachers and students are key in developing care (i.e. a teacher checking in with a student who is struggling emotionally). That said, theories of care have been further expanded by women of color to include a critical analysis of power. Thompson (1998) points out that educational caring cannot be color-evasive (Annamma, Jackson, \& Morrison, 2017) or powerblind. Intersectional caring is necessary in order to attend to relational power dynamics. For example, the concepts of politicized love and care (Darder, 2002) have pointed out communal forms of care in which educators are not only attuned to the personalized needs of students, but also take on a justice-oriented stance in their teaching to fight against systems of oppression alongside students. These critical conceptions of care offer educators a pedagogical approach that can foster a sense of community and belonging among students.

\section{Connecting Frameworks}

By implementing these critical theories, we have identified four streams that unite our curricular and pedagogical efforts: (1) Engage in self-reflection/praxis to promote ongoing contemplation and self-checking of personal biases and limited understandings based on our positionalities; (2) teach common theory vocabulary, language, and concepts throughout our courses so that students are scaffolded into higher learning; (3) Engage theory and language into practice through assignments, projects, and outside classroom experiences; (4) Emphasize how stereotyping and lack of critical understandings about the educational experiences of students of color can perpetuate structural inequalities in society. In the next section, we break down how our collective work shaped the curricular changes for each of our courses. These revisions were not individualized treatments, but rather we integrated this work to invite ongoing critical conversations and learning for our students. 


\section{THE COURSE REVISIONS}

Social justice courses in teacher preparation are essential to help PSTs meet the educational demands of diverse students. Unfortunately, over the past two decades such courses have been "phased" out of teacher preparation through the removal of social justice from teacher accreditation standards and the addition of methods or assessment courses (Aronson \& Anderson, 2013; Butin, 2007). Research shows that one single course is not enough to impact PSTs beliefs and pedagogy toward teaching students across race, class, gender, sexuality, or ability (Mills \& Ballantyne, 2010). Thus, through our interdisciplinary SJTE, we worked through these constraints by centering social justice within required foundational courses for PSTs. Below we share how these "typical" courses in teacher education programs changed through our collective work. While our narrative focuses largely on the conceptual and theoretical underpinnings of the course revisions, we provide specific examples of content, pedagogical, and cultural shifts within the courses in Figure 1.

Figure 1. Social Justice Teaching Collaborative Curriculum Changes

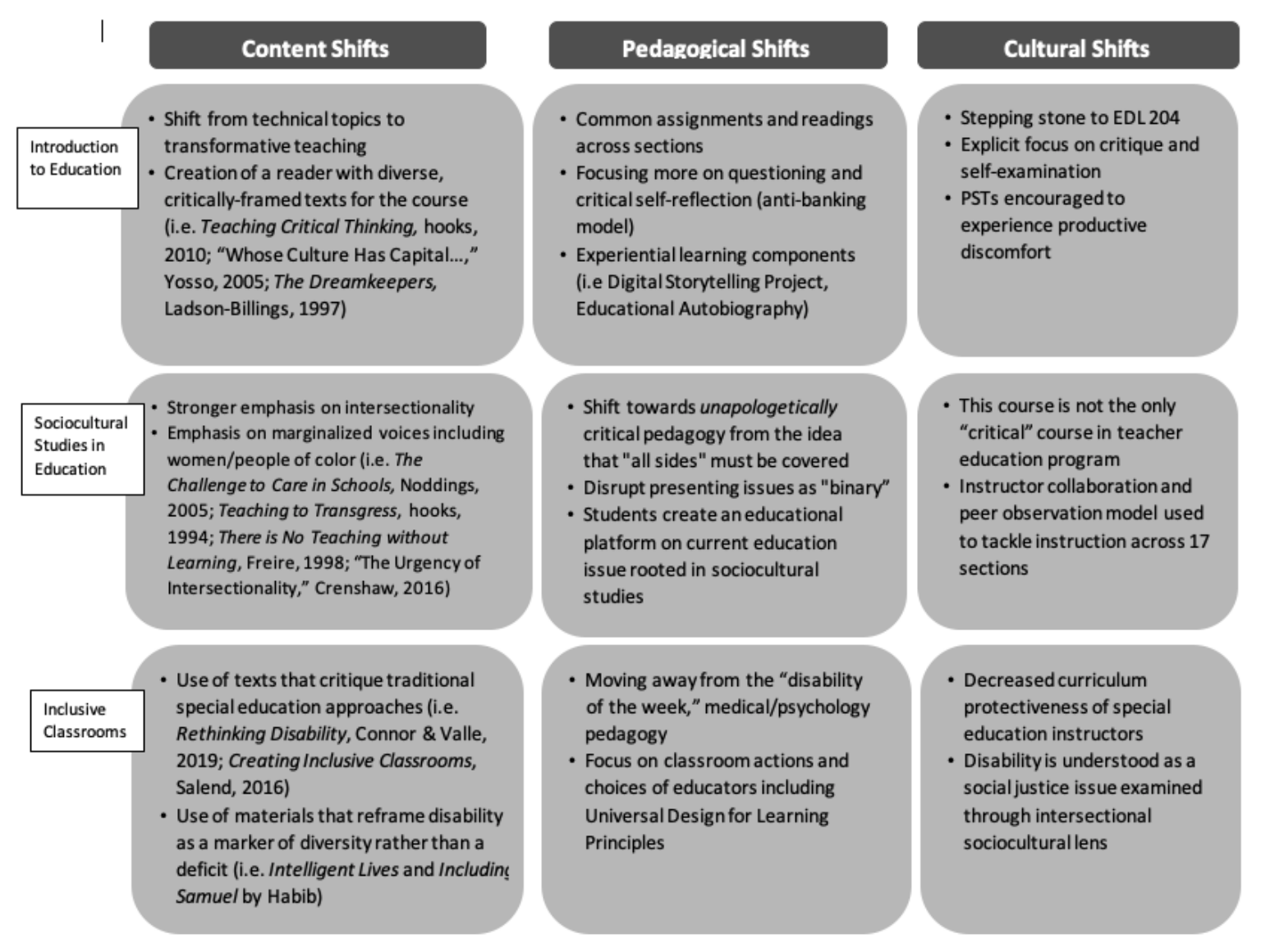




\section{EDT 190 Introduction to Education}

Introductory courses within teacher education programs play a vital role as they must both interrupt existing dominant narratives that PSTs bring with them from previous schooling and (re)frame the narrative of the entire program (Feiman-Nemser \& Featherstone, 1992). During initial planning meetings we worked to leverage the critical frameworks outlined above to deliberate around two questions: "what initial experiences should PSTs have?" and "what initial ideas should PSTs be exposed to?" in an introductory class to begin conversations about socially just curriculum and pedagogy. We did this in order to interrupt a rigid focus on technical aspects of teaching and instead create awareness of the sociocultural aspects of schooling. We developed this introductory course to raise awareness about the unquestioned, common sense notions of traditional schooling (Kumashiro, 2015), knowing that PSTs will explore these concepts in greater depths in other courses.

Out of our critical theoretical orientation and conversations, we developed guiding questions and re-envisioned the state's mandated themes and our department's curriculum goal for the course to "challenge candidates to become critically conscious curriculum makers for social justice, in solidarity with communities, within diverse contexts." Readings, activities, assignments and class conversations prompt students to critically reflect on their common sense answers to these seemingly simplistic, yet complex questions: (1) What does it mean to teach?, (2) What is the purpose of school?, and (3) How do college students become transformative teachers?

Four course themes take up these questions. The first theme focuses on the aims of education and the role of schools in a democratic society. For this theme, PSTs begin to grapple with the historical purposes of schooling and the evolution of the current functions of schools. PSTs are positioned to ask critical questions like "who was included" and "who benefits" in order to uncover the power structures of schools used for discipline and control. This allows students to reevaluate their own past educational experiences in relation to what they learned in school and what they were allowed to ignore.

Explicit attention is given to the notion of critical thinking, and learning through discomfort (hooks, 2009; Wheatley, 2002). This is an intellectual practice we ask PSTs to engage in. For example, they get an introduction to "othering" (Brown, 2005) and how it occurs across diversity markers to position certain students as "normal" and allows students to critically question these existing social norms that impact classrooms and society. Critical thinking asks PSTs to confront their own privilege (Mclntosh, 1990) as unearned benefits not equally afforded to all individuals. Here PSTs begin thinking about the role of teachers in democratic education... past, present, and into the future; what it means to get an education in a democratic society; how democratic is U.S. schooling; who gets included and excluded; and what are some contradictions (hooks 2010; Collins, 2007) in the U.S. system of education. This knowledge sets the stage for the second theme in which we dig deeper into the current context of U.S. schooling and explore these contexts through the lived experiences of teachers and students in classrooms. 
The second theme delves into the economic, legal and political context of schools. Here, PSTs are exposed to 1) the historical, social, political, and economic development of the U.S education system, and 2) basic critical reading skills. This theme provides an introduction to the sociocultural foundations of schooling in which we highlight the context of schooling from the point of view of PSTs who have been "othered" due to race, gender, class, sexuality, language, immigration status, ability, etc. PSTs consider how learning about multiple experiences and perspectives gives them a much more comprehensive view of the world and how teachers can serve their students in ways that validate students' diverse backgrounds. PSTs begin to understand that schooling experiences differ because of varying social identities, and this becomes part of the third theme, the practice of becoming a culturally competent and caring teacher.

The third theme highlights the importance of culturally responsive and inclusive education. This is the pedagogical and curricular framework that we utilize as a response to the injustices that targeted students are facing both inside and outside of the classroom. This theme becomes important after grappling with themes 1 and 2 which delve into historical and present contexts. Theme 3 focuses on praxis as a way to address social inequalities rather than engage in token lip service to celebrating diversity. This is perhaps the most uncomfortable work for PSTs whose dominant identity markers (male, white, cisgender, able-bodied, etc) position them to view current systems as 'normal' and 'just'. In this course PSTs are required to unpack the concept of socialization and to deeply interrogate their existing opinions, where they came from, and how experiences in places like schools can be different based on intersectional identities. We ask PSTs to confront the notion that there is a difference between personally held opinions (which everyone has based on personal experiences) and developing informed knowledge (that comes from the diverse course texts where the experiences others should expand and deepen PSTs' perspectives and can liberate them) (Sensoy \& DiAngelo, 2017).

Some questions we ask PSTs to consider: Will they rely solely on their own positionality and experience to teach, or will they take on the intellectual challenge to allow the experiences and perspectives of their students to imbue their practice? Will they teach to simply bank information into their students to meet technocratic standards, or will they value the local community assets knowledge students bring into the classroom? Will they be open to considering pathways for creating inclusive learning environments that simultaneously challenge school norms that privilege certain students at the cost of others? In this sense, we define what we mean by transformative teacher. It is important for PSTs to understand that social justice is not a special interest agenda that gets in the way of learning, but rather, social justice teaching is the foundation for what enables students and teachers to become engaged in school and find meaning, purpose, and belonging in the classroom.

The fourth theme, ethics and professionalization, helps PSTs understand and grapple with the complexities of the teaching profession. Through this theme we challenge PSTs to think more critically about what it means to be a "professional" within the field of teaching as we position teachers as intellectuals. To "intellectualize" teaching and learning is to confront the 
current nature of schools and then theorize/ reconceptualize the way schools operate today. This is part of an ongoing, de-normalizing process required to consider alternatives to traditional ways of teaching and learning. Throughout the semester, students should be acquiring a scholarly language of social inequality and how it works in order to 1) discuss it in an academic context; and 2) eventually take action against it. By continuing to use the critical lens introduced early in the semester, PSTs can challenge limited, deficit notions of "being professional" and "disobedience" in order to see themselves as powerful advocates for students.

\section{EDL 204 Sociocultural Studies in Education}

Courses in history, philosophy, sociology, and psychology of education have been included in teacher preparation in the U.S. as early as the 1930s. In 1929, William Kirkpatrick, a philosopher of education at Teachers College, recruited a group of interdisciplinary scholars to build upon the ideas of John Dewey and discuss how the commonalities amongst their disciplines could aid future teachers to be more effective with students in a changing world (Butts, 1993). Tozer (1993) explains that the interdisciplinary field called "Social Foundations of Education" (SFE) emerged with a commitment to prepare PSTs to contribute to the political and social welfare of diverse groups of students. What has commonly become known as SFE draws on multiple disciplines and includes topics ranging from the history and purposes of schooling as well as "moral, civic, and social dimensions of education" (Beadie, 1996, p. 77). Ultimately, SFE courses rely on interdisciplinary perspectives that seek to investigate education through a philosophical, historical, sociological and political lens.

Our SFE course, "Sociocultural Studies in Education," is taught using a cultural studies approach. SFE courses across teacher education programs in the U.S. vary greatly in both content and pedagogy and do not always explicitly align with social justice aims. At our campus, EDL 204 is a required class for all PSTs, but also fulfills a university liberal arts requirement, so it brings in many majors across campus. In 2016, Aronson was hired for a new role in which she was charged with revising the SFE curriculum taught across 17 sections. Over the course of a year she conducted informal interviews with colleagues and former instructors, studied syllabi at other institutions, and spoke with experts in the field to truly grasp the needs of the course and to gain many perspectives. Soon after her hire, she met with the SJTC to discuss possibilities for EDL 204. While considering the changes that had been made for EDT 190, the SJTC members brainstormed objectives for what we wanted our students to get out of EDL 204 and how this would differ from 190 and other teacher education courses. We plotted major concepts, theories, and possible readings to include in EDL 204. We also discussed possible major assignments across these courses and how we could build them to foster PSTs pedagogical growth throughout their teacher preparation. Aronson then took all this feedback and constructed a "master curriculum" that would be used by all the instructors of the course. SJTC members also reviewed and offered feedback on the final curriculum.

After dialogue with all the SJTC members, the final course question devised for EDL 204 asks: What does it mean to educate children to live in a pluralistic democratic society? We also 
ask several sub-questions: (1) How do social norms and political climates impact individual choices, access, or opportunities in school?; (2) How does an historical understanding of schooling create tensions for moral aspects of schooling today?; and (3) How can we a) develop cultural competence (raise awareness) about the oppressive aspects of schooling while b) learning to navigate anti-oppressive education?

We organized the course around three units each with their own objective(s). Unit 1 is focused on the "Foundations of Education " with an objective to focus on the role of being a community member in a pluralistic democracy centered on social justice. Within this first unit we build off of EDT 190 to distinguish between "education and schooling" (Quantz, 2016) and introduce PSTs to the complexity of "democracy" (Collins, 2007). SFE is also presented as a discipline with philosophical concepts such as pluralism, epistemology, theory, paradigm, ontology, ethics and morals. During this unit, we also introduce students to critical pedagogy. In Aronson's design of EDL 204, she situates the class "unapologetically" through a critical pedagogy lens. Thus, PSTs are introduced to critical pedagogy and concepts such as cultural capital, hegemony, discourse, and hidden curriculum, with an understanding that this course is taught from that perspective. Although many of the voices in SFE historically are white men, our curriculum centers these voices of women and people of color in the curriculum; PSTs are expected to place white, male educational philosophers like John Dewey in conversation with W.E.B. Dubois, Carter G. Woodson, and Anna Julia Cooper.

Unit 2, the bulk of the semester-long course, again builds from the work started EDT 190 by 1 ) focusing on how schools' perpetuate inequality 2) making connections between the historical and the contemporary in relation to issues of social inequalities and the construction of identities such as sexuality, race, gender, and social class and 3) understanding how issues and actions in broader society impact what happens inside of schools. Throughout this unit, PSTs are introduced to both theory and history. We begin with an introduction to intersectionality, intentionally connecting to its roots in the experiences of Black women, (Crenshaw, 2016; Sensoy \& DiAngelo, 2017) as a starting point for PSTs to understand all the systems of oppression we investigate should be done through an intersecting lens. Students are also introduced to concepts such as identity, positionality, power, privilege, and oppression. With this foundation set, we study various histories of social groups/identities across class, indigenous, African Americans, Latinx and Asian communities, whiteness, disability, gender and sexuality. Over the course of Unit 2, PSTs are introduced to feminism, capitalist critiques (brief introduction to Marxism), decolonialism, critical race theory, DisCrit, critical whiteness studies, and queer theory.

Finally, in Unit 3 we focus on "Action, Community, and Praxis" which carries over the last objective of Unit 2 and also charges PSTs to become community members engaged in social action and to seek imagination for change. In this final unit, PSTs are introduced to critical educational policy through the works of Jean Anyon (2014), Ayers, Kumashiro, Meiners, Quinn, and Stovall (2016), and Bettina Love (2019). They also begin to unpack political ideology and how this influences policy decisions. Finally, as a means to encourage action, we do an in-depth 
analysis of culturally sustaining pedagogy (Irizarry, 2017) and a case study of the Raza Studies Ethnic Studies ban and court case win.

\section{EDP 256 Inclusive Classrooms}

Teacher preparation in special education draws from the medical/psychological model of disability in which disability is perceived as a deficit within the student. This makes it difficult or impossible for the student to be successful in a "typical" education classroom without specialized support. Connor et al. (2015) describe this approach as "predicated upon scientific, medical and psychological understanding of human difference" (pp. xiii). This perspective of disability results in the development of a separate education track that carries stigma, separates children from the general curriculum and their peers, lowers standards, and limits opportunity. It is rooted in "long-held cultural beliefs about children with disabilities being qualitatively different from children without disabilities" (Connor \& Valle, 2011, p.11) thereby designating special education for students with disabilities. Despite recent efforts at inclusion, high stakes testing has prompted the segregation of students with disabilities to minimize the liability of students' test scores on teacher evaluations. This trend perpetuates racist practices that overidentify and segregate students of color (Ferri, 2016; Connor, Ferri \& Annamma, 2016). While "inclusion" has been mainstreamed in schools, few teachers are prepared to rigorously implement inclusive teaching practices. Teacher preparation has failed to "...imagine the possibilities beyond the parameters of inherited institutional practice" (Ware, 2005, as cited in Gabel, 2009, p.105).

Moreover, efforts at merging general education and special education teacher preparation at an institutional level are minimal due to demands on time, curriculum protectiveness, and lack of knowledge about the educational experiences of students with disabilities (Llasidou, 2011; Harry \& Klingner, 2014). Disability has long played a fourth fiddle to justice issues like race, class and gender in education. Through our SJTC work, we have developed a systematic approach to infusing critical studies in all aspects of social justice for PSTs.

Using disability studies in education we have centered the voices of the disabled to redesign the EDP 256 Inclusive Classroom introductory course. This course was previously rooted in the medical model, but has now changed to a course focusing on how to develop inclusive classrooms that meet the learning needs of a wide range of students. Through a Disability Studies in Education (DSE) framework, we situate disability within social, cultural, and political contexts to understand how and why it is constructed as an individualized deficit. This approach reveals how special education practices are discriminatory and places the onus of accessibility on individualized accommodations, rather than a communal responsibility of general curriculum and schooling to fundamentally change to become more accessible (Gabel, 2009). Harmful practices in special education includes the disproportionate representation of children of color, especially males, in special education feeding into the cradle/school-to-prison pipeline (Annamma, 2015; Connor et al., 2015; Connor et al., 2016). 
DSE provides an opportunity to "...critique and change oppressive practices currently taking place in schools..." (Cosier \& Ashby, 2016, p. 7). Universal design for learning (UDL), in particular, shifts the mindset and attitude of teachers to develop actual inclusive classrooms. EDP 256 begins with an exploration of how students understand disability and how social norms perpetuate stereotypes and stigma about disability. PSTs then learn about the medical/psychological model and social model of disability to understand the difference between treating individuals as deficient (former) versus examining how social structures disable people (latter). Students use the social model lens to examine how special education policy and social attitudes institutionalize discriminatory and disabling practices into schools. PSTs are also asked to understand disability as a marker of human diversity rather than a deficiency.

We have adopted new texts for this course (see Figure 1 ) that critique traditional special education practices and provide approaches that change classroom practice rather than children. These texts are supplemented by discussions about current research regarding the disproportionate representation of certain students in special education. Films such as Dan Habib's Intelligent Lives and Including Samuel are used to highlight disability as a marker of diversity rather than a deficit that requires remediation. This work builds on the systematic readings strategically included in earlier required coursework (i.e. EDT 190 and EDL 204) to address other aspects of social justice in education.

These revisions have been underway for years and are now fully implemented in 2019. Not only are we observing PSTs understanding disability through a critical lens, but the SJTC work and course revisions as a whole has also shifted PSTs' thinking about privilege, racism, and classism. PSTs have built up the skills in critiquing policy and social attitudes that work from a deficit lens. Observing the change in our PSTs renews our hope in promoting meaningful change in classrooms resulting in greater equity for all students. Inciting such change in teacher preparation from the grassroots level promises more expedient impact in the classroom, rather than trying to prompt reform from top down policy changes. We feel encouraged that children will experience greater educational equity under the instruction of teachers prepared through social justice.

\section{DISCUSSION AND IMPLICATIONS}

We have shared our process and efforts in creating courses centered in social justice. However, this is not a "how to" guide in implementing social justice in teacher education. We recognize that our geographic context, our students, and who we are as professors shapes the pedagogical and curricular choices we make. That said, our collaborative work does offer examples of how faculty can organize around SJTE to advocate for curriculum changes at their own respective institutions.

While we consider these beginnings to be successful at our institution and have yielded positive results in terms of students' social justice growth (Wrononski et al., under review), we recognize that more work must be done, and data collected to support SJTE. Data supporting 
the positive results of our curricular changes will add to the literature on the need for critical teacher education, as well as continue to garner support for this approach within our departments and division. With a growing mass of critical educators, PSTs will experience a more coherent and cohesive message in their preparation, increasing the likelihood they will enter their classrooms with the efficacy to take on social issues. While many teacher educators are fine with the "one and done approach" (one course that "covers" all social justice topics), we argue that the tenets of social justice should be embedded across all courses within teacher preparation programs. If we truly want equity and justice in educational settings, we must be willing to reimagine the way we prepare PSTs. We started this process through our SJTC with the long-term goal of implementing this approach across the curriculum. To accomplish this goal, we must continue fostering relationships with other faculty members and welcome more colleagues into the fold of our collaborative work. This also requires professional development for us and our colleagues.

While we have seen success building a foundation for social justice with the PSTs we work with, we also face challenges once students leave our courses. Many of our students have informally shared that their block courses, which are courses that are taken together during a certain times of their program, and often connected to a field experience, are heavily comprised of methods classes where the emphasis on social justice seems to fade away. This by no means suggests that all our "methods" professors are not interested in social justice, in fact there are a few who continue to think about ways to incorporate more social justice material in their courses. However, it does shed light on this divide that continues to exist in many teacher education programs between what students see as "theory" and "practice" classes, and that we often perpetuate as teacher educators. In order for us to advance the work of the SJTC, we must continue to advocate for social justice to be integrated throughout our entire teacher preparation program in intentional and meaningful ways. This is often easier said than done of course, especially given the fact that many of us leading this change are junior or contingent faculty at our university with less power than those who are already tenured (at the time of this writing one member of the SJTC is tenured and another is going up for tenure currently). We still face challenges of getting buy-in from all faculty members, but we remain hopeful with the support from our college administrators that we have been able to take these small steps to break these barriers. Nevertheless, we aim to continue this work and continue to build SJTE.

We, as higher education faculty, and our teacher education students face numerous sociopolitical and organizational challenges on our journeys in SJTE. However, our PSTs are likely to confront similar systemic challenges to their social justice work once they enter the teaching profession, and it has been widely recognized that educational leaders are critical mediators of social justice praxis in schools (Theoharis, 2007; Theoharis \& O'Toole, 2011). While principals and other educational leaders have the potential to assist in addressing systemic social justice challenges, the educational leadership field recognizes that this type of critical social justice leadership is not the norm. Educational leaders, like teachers, face a myriad of demands from multiple stakeholders who frequently have competing interests, and this creates leadership 
tensions that, if not confronted with an explicit social justice lens, tend to favor the bureaucratic and accountability-driven status quo that all too often runs counter to social justice aims (Capper \& Young, 2014). Although the need for social justice educational leadership has been well described, we see the field of teacher education advancing in terms of a commitment to social justice, while this same commitment is lagging in educational leadership preparation programs (Horsford, Scott, \& Anderson, 2018). Teachers and administrators alike need to be prepared for social justice teaching and leadership so that communities of solidarity can be built within school spaces (Furman, 2012; Theoharis \& Causton, 2014). We cannot send teachers into schools without the support of social justice-minded leaders. This is something we aim to work on in future research as we build partnerships with our educational leadership program.

\section{Acknowledgements}

The authors would like to thank their college for internal funding and support while navigating these curricular changes.

\section{REFERENCES}

Annamma, S. A., Jackson, D. D., \& Morrison, D. (2017). Conceptualizing color-evasiveness: Using dis/ability critical race theory to expand a color-blind racial ideology in education and society. Race Ethnicity and Education, 20(2), 147-162.

Annamma, S. A. (2015). Whiteness as property: Innocence and ability in teacher education. The Urban Review, 2(47), 293-316.

Anyon, J. (2014). Radical possibilities: Public policy, urban education, and a new social movement. (2nd Ed.). Routledge.

Aronson, B., \& Anderson, A. (2013). Critical teacher education and the politics of teacher accreditation: Are we practicing what we preach? Journal for Critical Education Policy Studies (JCEPS), 11(3), 244-262.

Ayers, W., Kumashiro, K., Meiners, E., Quinn, T., \& Stovall, D. (2016). Teaching toward Democracy 2e: Educators as agents of change. (2nd Ed). Routledge.

Baldwin, J. (1963). "A Talk to Teachers" The Saturday Review

Bell, D. (1980). Brown v. Board of Education and the interest-convergence dilemma. Harvard Law Review, 518-533.

Bell, D. (1992). Faces at the bottom of the well. Basic Books.

Butts, R. F. (1993). In the first person singular: The foundations of education. Caddo Gap Press.

Beadie, N. (1996). From "teacher as decision maker" to teacher as participant in "shared decision making": Reframing the purpose of social foundations in teacher education. Teachers College Record, 98, 77-103.

Butin, D. W. (2007). Dark times indeed: NCATE, social justice, and the marginalization of multicultural foundations. Journal of Educational Controversy, 2(2), 1-17.

Capper, C. A., \& Young, M. D. (2014). Ironies and limitations of educational leadership for social justice: A call to social justice educators. Theory into Practice, 53(2), 158-164. 
Cochran-Smith, M., Shakman, K., Jong, C., Terrell, D. G., Barnatt, J., \& McQuillan, P. (2009). Good and just teaching: The case for social justice in teacher education. American Journal of Education, 115(3), 347-377.

Collins, P.H. \& Bilge, S. (2016). Intersectionality. Polity Press.

Collins, P. H. (2009). Another kind of public education: Race, schools, the media, and democratic possibilities. Beacon Press.

Collins, P. (1990). Black feminist thought: Knowledge, consciousness and the politics of empowerment. Routledge.

Connor, D., Ferri, B., \& Annamma, A. (Eds.) (2016). DisCrit: Disability studies and critical race theory in education. Teachers College Press.

Connor, D., Valle, J. \& Hale, C. (2015). Practicing disability studies in education. Peter Lang.

Cook, D. A. (2015). Shifting the center in teacher education: An introduction to the special issue on Critical Race Theory and teacher education. The Urban Review, 47(2), 233-236.

Cosier, M., Ashby, C. (2016) Enacting change from within: Disability studies meets teaching and teacher education. Peter Lang.

Crenshaw. K. (2016, October). The urgency of intersectionality. [Video file]. Retrieved from https://www.ted.com/talks/kimberle crenshaw the urgency of intersectionality?lan guage $=$ en

Crenshaw, K. (1991). Mapping the margins: Intersectionality, identity politics and violence against Women of Color. Stanford Law Review, 43(6), 1241-99.

Darder, A. (2002). Reinventing Paulo Freire: A pedagogy of love. Westview Press.

Dewey, J. (1938). Experience and Education. Kappa Delta Phi.

Dewey, J. (1935). The teacher and his world. The Social Frontier, 1(4), 7.

Delgado, R., \& Stefancic, J. (2012). Critical race theory: An introduction. (2nd ed.). New York University Press.

Dover, A. G. (2013). Teaching for social justice: From conceptual frameworks to classroom practices. Multicultural perspectives, 15(1), 3-11.

Elenes, A.C. (2001). Transformando fronteras: Chicana feminist transformative pedagogies, International Journal of Qualitative Studies in Education, 14(5), 689-702.

Enterline, S., Cochran-Smith, M., Ludlow, L.H., \& Mitescu, E. (2008). Learning to teach for social justice: Measuring change in the beliefs of teacher candidates. The New Educator, 4, 267-290.

Furman, G. (2012). Social justice leadership as praxis: Developing capacities through preparation programs. Educational Administration Quarterly, 48, 191-229.

Gorski, P. C., Davis, S. N., \& Reiter, A. (2013). An examination of the (in) visibility of sexual orientation, heterosexism, homophobia, and other LGBTQ concerns in US multicultural teacher education coursework. Journal of LGBT Youth, 10(3), 224-248.

Harding, S. (Ed.). (1987). Feminism and methodology: Social science issues. Indiana University Press.

Harris, C. I. (1993). Whiteness as property. Harvard Law Review, 1707-1791. 
Harris, B. G., Hayes, C., \& Smith, D. T. (2019). Not a 'Who Done it' mystery: On how whiteness sabotages equity aims in teacher preparation programs. The Urban Review, (0123456789).

Horsford, S. D., Scott, J. T., \& Anderson, G. L. (2018). The politics of education policy in an era of inequality: Possibilities for democratic schooling. Routledge.

hooks, b. (2010). Teaching critical thinking: Practical wisdom.: Routledge.

hooks, b. (1994). Teaching to transgress: Education as the practice of freedom. Routledge.

Feiman-Nemser, S., \& Featherstone, H. (1992). Exploring teaching:reinventing an introductory course. Teachers College Press.

Friere, P. (1970). Pedagogy of the oppressed. The Continuum International Publishing Group Inc.

Gabel, S. (2009). Disability studies in education: Readings in theory and method. Peter Lang.

Gorski, P. C., Davis, S. N., \& Reiter, A. (2013). An examination of the (in) visibility of sexual orientation, heterosexism, homophobia, and other LGBTQ concerns in US multicultural teacher education coursework. Journal of LGBT Youth, 10(3), 224-248.

Grant, C. A., Brown, K. D., \& Brown, A. L. (2016). Black Intellectual Thought in Education: The Missing Traditions of Anna Julia Cooper, Carter G. Woodson, and Alain LeRoy Locke. Routledge

Hytten, K. (2017). Democracy and Education in the United

States. http://education.oxfordre.com/view/10.1093/acrefore/9780190264093.001.00 01/ crefore-9780190264093-e-2

Irizarry, J. G. (2017)"For Us, By Us": A Vision for Culturally Sustaining Pedagogies Forwarded by Latinx Youth. In D. Paris \& S. H. Alim (Eds.), Culturally sustaining pedagogies: Teaching and learning for justice in a changing world. Teachers College Press.

Kincheloe, J. L. (2004). Critical pedagogy primer (2nd Ed.). Peter Lang Publishing, Inc. Leonardo, Z. (2013). Race frameworks: A multidimensional theory of racism and education. Teachers College Press.

Liu, K., \& Ball, A. F. (2019). Critical Reflection and Generativity: Toward a Framework of Transformative Teacher Education for Diverse Learners. Review of Research in Education, 43(1), 68-105.

Love, B. L. (2019). We want to do more than survive: Abolitionist teaching and the pursuit of educational freedom. Beacon Press.

Matias, C. E., \& Mackey, J. (2016). Breakin' down whiteness in antiracist teaching: Introducing critical whiteness pedagogy. Urban Review, 48(1), 32-50.

Mills, C. \& Ballantyne, J. (2016). Social justice and teacher education: A systematic review of empirical work in the field. Journal of Teacher Education, 67(4), 263-276.

Mills, C., \& Ballantyne, J. (2010). Pre-service teachers' dispositions towards diversity: Arguing for a developmental hierarchy of change. Teaching and Teacher Education, 26(3), 447454. 
Milner, H. R. (2017). Race, talk, opportunity gaps, and curriculum shifts in (teacher) education. Literacy Research: Theory, Method, and Practice, 66(1), 73-94.

Moraga, C., \& Anzaldúa, G. (Eds.). (1983). This bridge called my back: Writings by radical women of color (2nd ed.). Kitchen Table/Women of Color Press.

Naples, N. A. (2009). Teaching intersectionality intersectionally. International Feminist Journal of Politics, 11(4), 566-577.

Nieto, S. (2000). Placing equity front and center: Some thoughts on transforming teacher education for a new century. Journal of Teacher Education, 51(3), 180-187.

Noddings, N. (2013). Caring: A relational approach to ethics and moral education. University of California Press.

Quantz, R. A. (2016). Sociocultural studies in education: Critical thinking for democracy. Routledge.

Sensoy, O., \& DiAngelo, R. (2017). Is everyone really equal?: An introduction to key concepts in social justice education (2nd Ed). Teachers College Press.

Spring, J. H. (1985). American education: an introduction to social and political aspects (3rd Ed). Longman.

Theoharis, G. (2007). Social justice educational leaders and resistance: Toward a theory of social justice leadership. Educational Administration Quarterly, 43, 221-258.

Theoharis, G., \& Causton, J. (2014). Leading inclusive reform for students with disabilities: A school-and systemwide approach. Theory Into Practice, 53(2), 82-97.

Theoharis, G., \& O'Toole, J. (2011). Leading inclusive ELL: Social justice leadership for English language learners. Educational Administration Quarterly, 47, 646-688.

Thompson, A. (1998). Not the color purple: Black feminist lessons for educating caring. Harvard Educational Review, 68(4), 522-554.

Tozer, S., \& Miretzky, D. (2005). Social foundations, teaching standards, and the future of teacher preparation. In D. W. Butin (Ed.), Teaching social foundations of education: Context, theories, and issues (pp. 3-27). Lawrence Erlbaum Associates, Inc.

Wheatley, M. J. (2002). Turning to one another: Simple conversations to restore hope to the future. San Francisco, CA: Berrett-Koehler Publishers.

Wronowski, M., Aronson, B., Banda, R., Kelly, M., Johnson, A., Reyes, G., \& Sander. S. (under review). Moving towards a comprehensive program of critical social justice teacher education: A QuantCrit analysis of pre-service teachers' perceptions of social justice education. Race, Ethnicity, \& Education.

Zeichner, K. M. (2009). Teacher education and the struggle for social justice. Routledge. 